\title{
Judy Chung Chuihua, Jeffrey Inaba, Rem Koolhaas and Sze Tsung Leong eds., Great Leap Forward
}

Cologne, Taschen, 2002, 721 pp.

\section{Gilles Guiheux}

\section{OpenEdition}

\section{Journals}

Édition électronique

URL : http://journals.openedition.org/chinaperspectives/267

DOI : 10.4000/chinaperspectives. 267

ISSN : 1996-4617

\section{Éditeur}

Centre d'étude français sur la Chine contemporaine

Édition imprimée

Date de publication : 15 avril 2003

ISSN : 2070-3449

\section{Référence électronique}

Gilles Guiheux, « Judy Chung Chuihua, Jeffrey Inaba, Rem Koolhaas and Sze Tsung Leong eds., Great Leap Forward », China Perspectives [En ligne], 46 | march-april 2003, mis en ligne le 29 août 2006, consulté le 21 septembre 2020. URL : http://journals.openedition.org/chinaperspectives/267 ; DOI : https://doi.org/10.4000/chinaperspectives.267

Ce document a été généré automatiquement le 21 septembre 2020

(c) All rights reserved 


\title{
Judy Chung Chuihua, Jeffrey Inaba, Rem Koolhaas and Sze Tsung Leong eds., Great Leap Forward
}

Cologne, Taschen, 2002, 721 pp.

\author{
Gilles Guiheux
}

\section{NOTE DE L'ÉDITEUR}

Translated from the French original by Peter Brown

1 The Pearl River Delta is without any doubt the region that has undergone the most radical transformation as a result of the past twenty years of reforms. Previously with low levels of industrialisation and urbanisation, today it is the primary source of Chinese exports, to which the two Special Economic Zones of Shenzhen and Zhuhai are major contributors. The Delta brings together 12 million inhabitants, and projections are for a tripling of the population by 2020 . The aim of this collective publication is to understand the new urban context that is emerging in the area.

2 The voluminous work of over 700 pages is not an academic publication and clearly sets out its playful side. The editor is a famous Dutch architect (Rem Koolhas) who is assisted here by his American colleagues, both architects and designers. The work is in fact the outcome of a study carried out in 1996 by students of architecture, landscape architecture and urban design at the Harvard Design School.

3 In his preface, Rem Koolhas justifies the undertaking by the absence of appropriate intellectual tools available to town planners to understand the processes at work in the region. According to him, the Delta's urban situation is characterised by what he calls "a city with exacerbated differences" (CWED). Whereas a traditional city seeks to produce a balance, a harmony and a certain degree of homogeneity, the CWED is based on the biggest differences possible between its various parts, differences that are both complementary and in competition with each other. The main characteristic of the 
CWED is not to tend methodically towards an ideal, but to exploit opportunistically the elements of chance, the fortuitous events and imperfections of the process. Accordingly, the work aims to make an important intellectual contribution to an understanding of current features of urban life. In order to do this, it constructs a series of notions that are humorously copyrighted by the authors in a glossary (pp. 702-709). Certain concepts seem to us to be operational like that of the CWED or of suburbia, defined as the essence of urbanisation in China, a hybrid between the city and the country that brings together the "genetic" features of the contemporary Chinese city such as golf courses, pleasure parks and luxury apartments (p. 141). Some of the other concepts are more clearly ironical (such as the cultural desert, "a Chinese euphemism for the Delta" or the Great Leap Forward for "the conversion of rice paddies and villages into postmodern villas and office towers") or outright obscure ones ("oracular magic").

The editorial part of the work brings together interesting contributions. We learn that the profit margins in the construction industry in China are never below $30 \%$ while being on average between $6 \%$ and $8 \%$ in the rest of the world (p. 173). There is also some useful information on the architectural profession (pp. 156-167). Three chapters are specifically devoted to the cities of Shenzhen, Zhuhai and Dongguan. The first of these accounts for a certain number of paradigms of the reform process, such as the district called "Overseas Chinese Town", intended to be a self-sufficient city, a sort of enclave within an enclave. It is also in Shenzhen that an emblem of the contemporary Chinese city, the revolving restaurant, was invented and mass produced (there are ten of them in a single confined area). Zhuhai aims to be a "garden city", that owes much to the dynamism of its mayor, Liang Guangda, the force behind the city's symbol: the theme park based on the Yuan Ming Yuan. In the chapter devoted to Dongguan, the writer publishes a part of her notebook and thereby has us meet the various players in the city's development-real estate agents, developers and businessmen-and their haunts-construction sites, golf courses, offices, luxury restaurants, bars for meeting prostitutes, and hotels where the rooms are rented by the hour.

The work's most important contribution is not, however, its editorial component. Rather it is the set of incomparable pictures it shows us. It is difficult to draw up an exhaustive list of the realities laid out for the reader's gaze. From the opening pages of the work these realities are the billboards of the real estate developers that unrelentingly line the byways of the Delta, which are all the more necessary in that the flats are sold even before the apartment blocks rise from the ground and that they are therefore the only sight that the purchasers have of their future property. These realities are also the polluting and dilapidated factories that lie scattered throughout the countryside, a legacy of the Great Leap Forward; the countless plans for urban development in Shenzen or Zhuhai; the office blocks that are constructed more quickly here than anywhere else in the world; the districts that house the migrant population living in Shenzhen; a plaster statue of Hercules in the garden of a holiday village in Zhuhai, or a tree pruned in the shape of a dragon at a road junction. They also include the politicians who have made the region over the past twenty years: Deng Xiaoping and Chris Patten; and finally, the spectacular transport infrastructure of motorways, railways, ports and airports.

6 Admittedly, the work raises more questions than it answers, but it does not forget the challenges facing the region, notably that concerning the collaboration between 
competing administrative or political entities ${ }^{1}$. In short, this is a very worthwhile read, as it gives us a sense of the region's bubbling energy, and lets us see the Pearl River Delta not only as one of the world's most economically dynamic regions, but also as a terrain for urban, and hence social, experimentation.

\section{NOTES}

1. This is a competition that has led to absurd investments, such as the existence of five airports, the one at Zhuhai being used at less than $10 \%$ of its capacity. The work also lets us see the countless unfinished building projects that are also one of the characteristic features of the landscapes of the Delta 